\title{
PENENTUAN KADAR VITAMIN C BEBERAPA JENIS CABAI (Capsicum sp.) DENGAN SPEKTROFOTOMETRI UV-VIS
}

\author{
Lilis Rosmainar*, Widia Ningsih, Ni Putu Ayu, Haula Nanda \\ Politeknik Meta Industri Cikarang \\ *email: lilis_rosmainar@yahoo.com
}

Received 16 April 2018

Accepted 28 Mei 2018

\begin{abstract}
Abstrak
Vitamin $\mathrm{C}$ adalah salah satu zat gizi yang berperan sebagai antioksidan dan efektif mengatasi radikal bebas yang dapat merusak sel atau jaringan, termasuk melindungi lensa dari kerusakan oksidatif yang ditimbulkan oleh radiasi. Vitamin C banyak terdapat di buah, dan sayuran, salah satunya pada cabai. Vitamin $\mathrm{C}$ pada cabai memiliki fungsi sebagai antioksidan yang baik untuk tubuh (mampu meningkatkan daya tahan tubuh yang diserap oleh kalsium dalam tubuh.

Penelitian ini bertujuan untuk mengetahui kadar vitamin $\mathrm{C}$ yang terdapat pada beberapa jenis cabai dengan menggunakan metode spektrofotometri UV-Vis serta melakukan uji pendahuluan. Kadar vitamin $\mathrm{C}$ tertinggi yang diperoleh dengan menggunakan metode spektrofotometri pada panjang gelombang $200 \mathrm{~nm}$ yaitu pada cabai keriting merah $(50 \mathrm{~g} / 100$ g) dan diikuti oleh cabai jablay orange-merah (38 g/100 g), cabai rawit hijau (29 g/100 g), cabai merah besar ( $22 \mathrm{~g} / 100 \mathrm{~g})$, dan cabai hijau besar (9 g/100 g). Sedangkan berdasarkan uji pendahuluannya diperoleh bahwa semua cabai mengandung saponin, serta hanya cabai merah besar (sampel 1) dan cabai merah keriting (sampel 4) yang mengandung flavonoid.
\end{abstract}

Katakunci: capsicum, cabai, spektrofotometri.

\begin{abstract}
Vitamin $\mathrm{C}$ is one of the nutrients that act as antioxidants and effectively overcome free radicals that can damage cells or tissues, including protecting the lens from oxidative damage caused by radiation. Vitamin $\mathrm{C}$ is widely found in fruits, and vegetables, one of them in chili. Vitamin $\mathrm{C}$ in chili has a function as a good antioxidant for the body (able to increase the immune system absorbed by calcium in the body.

This study aims to determine the levels of vitamin C contained in some types of chili using UV-Vis spectrophotometry method and conduct a preliminary test. The highest levels of vitamin C obtained by using spectrophotometric method at $200 \mathrm{~nm}$ wavelength were on red curly pepper $(50 \mathrm{~g} / 100 \mathrm{~g})$ and followed by chili jablay orange-red $(38 \mathrm{~g} / 100 \mathrm{~g})$, green cayenne (29 g/100 g), red pepper large (22 g/100 g), and large green chili (9 g/100 g). While based on preliminary test it was found that all chilies contain saponins, as well as only large red pepper (sample 1) and red curly pepper (sample 4) containing flavonoids
\end{abstract}

Keywords: capsicum, chilly, spectrophotometry

\section{Pendahuluan}

Vitamin $\mathrm{C}$ adalah salah satu zat gizi yang berperan sebagai antioksidan dan efektif mengatasi radikal bebas yang dapat merusak sel atau jaringan, termasuk melindungi lensa dari kerusakan oksidatif yang ditimbulkan oleh radiasi. Status vitamin $\mathrm{C}$ seseorang sangat tergantung dari 
usia, jenis kelamin, asupan vitamin $\mathrm{C}$ harian, kemampuan absorpsi dan ekskresi, serta adanya penyakit tertentu. Rendahnya asupan serat dapat mempengaruhi asupan vitamin $\mathrm{C}$ karena bahan makanan sumber serat dan buah-buahan juga merupakan sumber vitamin C (Citraningtyas, 2013).

Vitamin $\mathrm{C}$ mempunyai peran penting terhadap tubuh manusia, dimana apabila tubuh manusia kekurangan vitamin $\mathrm{C}$ maka akan timbul gejala penyakit ini seperti sariawan, nyeri otot, berat badan berkurang, lesu, dan sebagianya. Didalam tubuh vitamin $\mathrm{C}$ menjalankan fungsinya seperti dalam sintesis kolagen, pembentukan carnitine, terlibat dalam metabolisme kolesterol, menjadi asam empedu, dan berperan penting dalam pembentukan neurotransmitter norepinefrin. Vitamin $\mathrm{C}$ juga termasuk antioksidan dalam tubuh. Pada dasarnya vitamin $\mathrm{C}$ didalam tubuh mampu berfungsi melindungi beberapasel/ molekul dalam tubuhseperti, protein, lipid, karbohidrat dan asam nukleat selain itu vitamin $\mathrm{C}$ dapat menjaga kehamilan, mencegah dari diabetes (Helmi, 2007).

Vitamin $\mathrm{C}$ banyak terdapat di buah, dan sayuran, salah satunya pada cabai. Vitamin C pada cabai memiliki fungsi sebagai antioksidan yang baik untuk tubuh (mampu meningkatkan daya tahan tubuh yang diserap oleh kalsium dalam tubuh, selain itu, Vitamin C juga termasuk yang paling mudah larut dalam air dan esensial untuk biosintesis kolagen (Rahmawati, 2009). Sehubungan dengan hal diatas, peneliti tertarik untuk mengetahui kadar vitamin $\mathrm{C}$ yang terdapat pada cabai dengan menggunakan metode spektrofotometri UV-Vis dan menguji fitokimianya.

\section{Metode Penelitian}

\section{Alat dan bahan}

Alat yang digunakan adalah corong, labu ukur, tabung reaksi, batang pengaduk, rak tabung, spektrofotometri UV-Vis, oven, erlemeyer, kaca arloji, gelas ukur, spatel, kertas saring, beaker glass, dan blender. Adapun bahan yang digunakan dalam penelitian ini adalah cabai merah besar (sampel 1), cabai rawit hijau (sampel 2), cabai jablay orange-merah (sampel 3), cabai keriting merah (sampel 4), cabai hijau besar (sampel 5), aquades, etanol teknis $\left(\mathrm{CH}_{3} \mathrm{CH}_{2} \mathrm{OH}\right) 70 \%$, aquades bebas $\mathrm{CO}_{2}$, asam askorbat murni $\left(\mathrm{C}_{6} \mathrm{H}_{8} \mathrm{O}_{6}\right)$, pereaksi mayer, pereaksi dragendorff, larutan $\mathrm{FeCl}_{3}$.

\section{Prosedur Penelitian}

Cabai yang masih segar diambil secara acak di pasar tradisional yang ada di Cikarang. Ada 5 jenis cabai yang diambil yaitu cabai merah besar (sampel 1), cabai rawit hijau (sampel 2), cabai jablay berwarna orange-merah (sampel 3), cabai keriting merah (sampel 4), cabai hijau besar (sampel 5). Semua cabai diuji pendahuluan atau analisis kualitatifnya dengan uji alkaloid, flavonoid, saponin, dan pemeriksaan tanin.

\section{Analisis kualitatif \\ Uji alkaloid}

Sebanyak $3 \mathrm{~mL}$ larutan cabai dilembabkan dengan cara menambahkan 3 $\mathrm{mL}$ amoniak $25 \%$, didalam tabung reaksi tambahkan $5 \mathrm{~mL}$ kloroform, lalu di kocok, dan ditetaskan pada kertas saring dan tambahkan pereaksi dragendroff. Hasil positif ditunjukan dengan perubahan warna merah atau jingga pada kertas saring.

\section{Uji flavonoid}

Sebanyak $3 \mathrm{~mL}$ larutan cabai ditambah $1 \mathrm{~mL}$ alkohol dan $1 \mathrm{~mL}$ asam klorida di dalam tabung reaksi, dikocok kuat. Hasil positif ditunjukan dengan terbentuknya warna merah, jingga, atau kuning pada lapisan alkohol.

\section{Uji saponin}

Sebanyak $3 \mathrm{~mL}$ larutan cabai di dalam tabung reaksi lalu dikocok selama 10 detik lalu diamkan selama 10 menit. Hasil positif ditunjukan dengan terbentuknya busa yang stabil. 


\section{Uji tanin}

Sebanyak $3 \mathrm{~mL}$ larutan cabai masukan ke dalam tabung reaksi lalu tambahkan $\mathrm{FeCl}_{3}(1 \%) \quad 3 \mathrm{~mL}$. Hasil positif bila terbentuk warna biru tinta atau hitam kehijauan.

\section{Analisis kuantitatif \\ Penentuan kadar vitamin $C$}

Cabai yang masih segar (5 jenis) dibersihkan dan selanjutnya diblender lalu dikeringkan di oven hingga menjadi bubuk cabai. Dilakukan penentuan panjang gelombang dengan menggunakan vitamin C standar dan kurva kalibrasi dengan konsentrasi 75 ppm, $150 \mathrm{ppm}, 750 \mathrm{ppm}$, 1500 ppm dengan aquades sebagai blanko. Bubuk cabai yang telah dihaluskan, masing-masing diambil dan ditimbang sebanyak $100 \mathrm{mg}$ lalu dimasukkan ke dalam beaker gelas dan ditambahkan dengan aquades bebas $\mathrm{CO}_{2}$ lalu disaring dan diambil filtratnya. Filtrat yang didapat, diencerkan dengan aquades bebas $\mathrm{CO}_{2}$ sampai tanda batas $100 \mathrm{~mL}$. Kemudian di ukur pada panjang gelombang yang sudah ditentukan sebelumnya.

\section{Hasil dan Pembahasan}

Dari hasil uji fitokimia terhadap 5 jenis cabai yang masih segar, didapatkan hasil (Tabel 1) yaitu tidak ada kandungan alkaloid pada setiap sampel, meskipun secara teori pada biji cabai harusnya mengandung alkaloid. Hal ini dikarenakan pada saat memblender cabai, tidak semua biji dihaluskan jadi hanya daging cabainya saja yang halus sehingga tidak terdeteksi adanya alkaloid. Sampel 1 dan sampel 4 terdeteksi mengandung flavonoid, menurut Wiyani pada tahun 1999, kandungan flavonoid pada buah cabai adalah quercetin dan luteolin). Sedangkan secara keseluruhan sampel $1-5$ mengandung saponin, hal ini sesuai dengan literatur dari jurnal ilmiah Sutomo tahun 2017.

Tabel 1. Hasil uji kualitatif beberapa cabai

\begin{tabular}{|c|c|c|c|c|c|}
\hline $\begin{array}{c}\text { Uji } \\
\text { Kualitatif }\end{array}$ & 1 & 2 & 3 & 4 & 5 \\
\hline Alkaloid & - & - & - & - & - \\
\hline Flavonoid & + & _ & _ & + & _ \\
\hline $\begin{array}{c}\text { Saponin } \\
\text { Tanin }\end{array}$ & + & + & + & + & + \\
\hline
\end{tabular}

Pada penentuan kadar vitamin C, dibuat larutan dengan konsentrasi 75, 150, 750 dan 1500 ppm. Pengukuran panjang gelombang maksimum dilakukan dengan mengukur larutan asam askorbat $75 \mathrm{ppm}$ dengan panjang gelombang $200-300 \mathrm{~nm}$. Hasil pengukuran absorbansi asam askorbat 75 ppm ditunjukkan pada Tabel 2.

Tabel 2. Pengukuran absorbansi asam askorbat $75 \mathrm{ppm}$

\begin{tabular}{cc}
\hline Panjang gelombang (nm) & Absorbansi \\
\hline 200 & 0,629 \\
205 & 0,437 \\
210 & 0,324 \\
215 & 0,262 \\
220 & 0,217 \\
225 & 0,188 \\
230 & 0,166 \\
235 & 0,148 \\
240 & 0,132 \\
245 & 0,116 \\
250 & 0,098 \\
255 & 0,086 \\
260 & 0,076 \\
265 & 0,073 \\
270 & 0,069 \\
275 & 0,066 \\
\hline
\end{tabular}

Dari Tabel 2 diperoleh nilai absorbansi tertinggi pada panjang gelombang maksimum asam askorbat adalah $200 \mathrm{~nm}$ dengan nilai absorbansi 0,629. Kemudian dilakukan penentuan kurva kalibrasi sehingga diperoleh persamaan:

$$
\begin{gathered}
\mathrm{Y}=0,001 * \mathrm{C}+0,56 \\
\mathrm{RSQ}=0,98960
\end{gathered}
$$




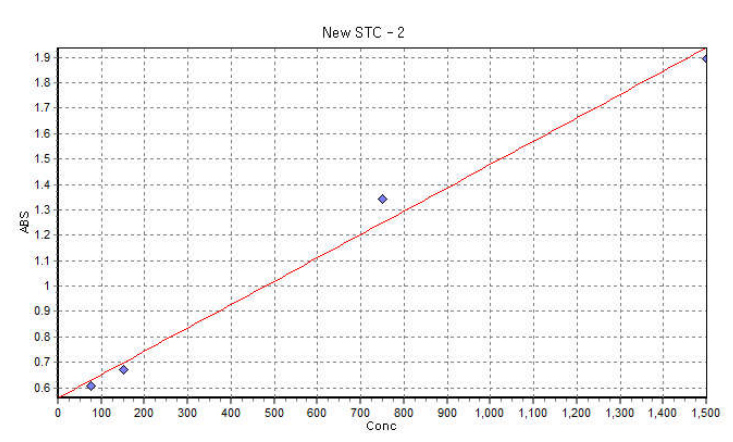

Gambar 1. Kurva Kalibrasi Vit.C

Hasil pengukuran kadar vitamin $\mathrm{C}$ pada beberapa jenis cabai dengan panjang gelombang $200 \mathrm{~nm}$ dapat dilihat pada Tabel 3. Berdasarkan hasil absorban yang diperoleh dan berdasarkan persamaan kurva kalibrasi yang telah dilakukan, maka dapat ditentukan kadar vitamin $\mathrm{C}$ yang terkandung dalam cabai ditunjukkan oleh Tabel 4.

Tabel 3. Absorbansi larutan sampel cabai pada panjang gelombang $200 \mathrm{~nm}$.

\begin{tabular}{cc}
\hline Sampel & Absorbansi \\
\hline 1 & 0,780 \\
2 & 0,854 \\
3 & 0,943 \\
4 & 1,059 \\
5 & 0,648 \\
\hline
\end{tabular}

Tabel 4. Kadar vitamin $\mathrm{C}$ pada berbagai cabai

\begin{tabular}{cc}
\hline Sampel & Kadar $(\% \mathrm{~b} / \mathrm{b})$ \\
\hline 1 & 22 \\
2 & 29 \\
3 & 38 \\
4 & 50 \\
5 & 9 \\
\hline
\end{tabular}

Berdasarkan data pada tabel 4 dan berdasarkan persamaan dari kurva kalibrasi yang diperoleh, maka, maka

\section{Daftar Pustaka}

Badriyah, L., (2015), Penetapan Kadar Vitamin C pada Cabai Merah (Capsium annum L.) Menggunakan Metode Spektrofotometri UV-Vis, Jurnal Wiyata, 2, p. 1 - 15. diketahui bahwa sampel 4 memiliki kadar vitamin $\mathrm{C}$ yang paling tinggi yaitu 50 g/100 g. Sampel lain berdasarkan urutan kadar yang paling tinggi sampai paling rendah adalah sampel $3(38 \mathrm{~g} / 100 \mathrm{~g})$, sampel 2 (29 g/100g), sampel 1 (22 g/100 $\mathrm{g})$, dan sampel 5 (9 g/100 g).

Berdasarkan U.S. RDA, kebutuhan vitamin $C$ untuk pria dan wanita sebanyak $60 \mathrm{mg} / \mathrm{hari}$, bayi senyakan $35 \mathrm{mg} / \mathrm{hari}$, ibu hamil sebanyak $70 \mathrm{mg} / \mathrm{hari}$, dan ibu menyusui sebanyak $95 \mathrm{mg} / \mathrm{hari}$ (Kamienshy, 2006). Dapat dikatakan bahwa berdasarkan kadar vitamin c tertinggi yang diperoleh pada sampel 4 $(0,49 \%)$ maka kebutuhan vitamin $\mathrm{C}$ dapat terpenuhi jika mengkonsumsi sampel 4 sebanyak 12-13 gr per hari. Sedangkan berdasarkan Widyakarya Nasional Pangan dan Gizi (2004), pria yang berumur 16-64 tahun membutuhkan vitamin $\mathrm{C}$ sebanyak $90 \mathrm{mg}$, sedangkan pada wanita umur 16-64 tahun dibutuhkan $75 \mathrm{mg}$. Namun kondisi ini bervariasi pada tiap individu.

\section{Kesimpulan}

Berdasarkan hasil penelitian penentuan kadar vitamin $\mathrm{C}$ pada berbagai jenis cabai dengan spektrofotometri UV-Vis pada panjang gelombang $200 \mathrm{~nm}$, maka diperoleh hasil kadar vitamin $\mathrm{C}$ yang tertinggi pada sampel $4(50 \mathrm{~g} / 100 \mathrm{~g})$ yaitu cabai keriting merah dan diikuti dengan urutan kadar selanjutnya sampel 3 (cabai jablay orange-merah) kadar $38 \mathrm{~g} / 100 \mathrm{~g}$, sampel 2 (cabai rawit hijau) kadar 029 $\mathrm{g} / 100 \mathrm{~g}$, sampel 1 (cabai merah besar) kadar $22 \mathrm{~g} / 100 \mathrm{~g}$ dan sampel 5 (cabai hijau besar) kadar $9 \mathrm{~g} / 100 \mathrm{~g}$.

Buhari, I., (2010), Analisis Kadar Vitamin C dalam Produk Olahan Buah Salak (Salacca zalacca) secara Spektrofotometri UV-Vis, Skripsi, Fakultas Ilmu Kesehatan Universitas Islam Negeri Alauddin. 
Kamiensky, Keogh, (2006), Vitamins and Minerals. In: Pharmacology Demystified. Mc.GrawHill Companies Inc., USA.

Nikmah, M., (2016), Pengaruh Natrium Benzoat Terhadap Kadar Vitamin C pada Cabai Rawit, Skripsi, Fakultas Sains dan Teknologi Universitas Islam Negeri Walisongo, Semarang.

Oktoviana, Y., Aminah, S., Sakung, J., (2016), Pengaruh Lama Penyimpanan dan Konsentrasi Natrium Benzoat Terhadap Kadar Vitamin C Cabai Merah (Capsicum annum L.), Jurnal Akademika Kimia, 1, p.193 -199.

Rahman, N., (2015), Analisis Kadar Vitamin C Mangga Gadung (Mangifera sp) dan Mangga Golek (Mangifera indica L) dengan Menggunakan Metode Iodimetri. Jurnal Akademika Kimia, 4, p. 33-37.
Riana, D., (2017), Ekstrak Daun Mangga (Mangifera indica L.) sebagai Antijamur Terhadap Jamur Candida albicans dan Identifikasi Golongan Senyawanya, Jurnal Kimia Riset, 2, p. 61-68.

Saleh, R., (2010), Generasi Baru Vitamin C, Health, Edisi Minggu Bisnis Indonesia, mirror.unpad.ac.id/koran/ bisnis/2010-12-19/bisnis_2010-1219_035.pdf

Sutomo, Rahmawati, A., Rizki, M., (2017), Standarisasi Buah Cabe Rawit Hiyung (Capsicum frutescens L.) Asal Tapin Kalimantan Selatan, Jurnal Ilmiah Ibnu Sina, 2, 245-253. 